\title{
Genetically Modified Mesenchymal Stromal/Stem Cells: Application in Critical Illness
}

\author{
Amir K. Varkouhi ${ }^{1}$ (D) - Ana Paula Teixeira Monteiro ${ }^{2,3} \cdot$ James N. Tsoporis ${ }^{2} \cdot$ Shirley H. J. Mei ${ }^{4} \cdot$ Duncan J. Stewart $^{4}$. \\ Claudia C. dos Santos ${ }^{2,5}$
}

Published online: 15 July 2020

(C) Springer Science+Business Media, LLC, part of Springer Nature 2020

\begin{abstract}
Critical illnesses including sepsis, acute respiratory distress syndromes, ischemic cardiovascular disorders and acute organ injuries are associated with high mortality, morbidity as well as significant health care system expenses. While these diverse conditions require different specific therapeutic approaches, mesenchymal stem/stromal cell (MSCs) are multipotent cells capable of self-renewal, tri-lineage differentiation with a broad range regenerative and immunomodulatory activities, making them attractive for the treatment of critical illness. The therapeutic effects of MSCs have been extensively investigated in several pre-clinical models of critical illness as well as in phase I and II clinical cell therapy trials with mixed results. Whilst these studies have demonstrated the therapeutic potential for MSC therapy in critical illness, optimization for clinical use is an ongoing challenge. MSCs can be readily genetically modified by application of different techniques and tools leading to overexpress or inhibit genes related to their immunomodulatory or regenerative functions. Here we will review recent approaches designed to enhance the therapeutic potential of MSCs with an emphasis on the technology used to generate genetically modified cells, target genes, target diseases and the implication of genetically modified MSCs in cell therapy for critical illness.
\end{abstract}

Keywords Mesenchymal stromal/stem cells $\cdot$ Critical illness $\cdot$ Gene therapy $\cdot$ Vector

Claudia C. dos Santos

Claudia.DosSantos@unityhealth.to

1 Department of Chemistry and Environmental Science, New Jersey Institute of Technology (NJT), Newark, NJ 07102, USA

2 Keenan and Li Ka Shing Knowledge Institute, University Health Toronto - St. Michael's Hospital, Toronto, Ontario, Canada
3 Institute of Medical Sciences and Department of Medicine, University of Toronto, Toronto, Ontario, Canada

4 Ottawa Hospital Research Institute and the University of Ottawa, Ottawa, ON, Canada

5 Interdepartmental Division of Critical Care, St. Michael's Hospital/ University of Toronto, 30 Bond Street, Room 4-008, Toronto, ON M5B 1WB, Canada 


\section{Introduction}

Acute organ failure (AOF) can occur in patients with critical illnesses including severe infections, early sepsis and ischemic disorders necessitating admission to intensive care units (ICUs) $[1,2]$. Sepsis can develop to more complex conditions leading to multiorgan dysfunction syndrome (MODS), which occurs as a response to pathophysiologic events and complicated interactions in body systems leading to immune, metabolic and hematologic dysfunctions [3, 4]. Sepsis associated with MODS is one of the leading causes of morbidity and mortality in ICUs worldwide [5]. In US, over 970,000 sepsis cases are admitted annually and sepsis accounts for more than $50 \%$ of hospital deaths [6]. Currently, aside from antibiotics and supportive care, there is no specific treatment for sepsis. Despite more than 104 Phase III clinical trials, no therapeutic intervention has emerged to reduce morbidity and mortality from sepsis and associated MODS [7, 8].

The morbidity and mortality rates due to ischemic disorders causing stroke, irreversible cardiomyopathy, kidney or liver failure and critical limb ischemia are also concerning $[9,10]$. In an ICU setting, supportive strategies are applied to care for patients with critical illnesses including: hemodynamic resuscitation, mechanical ventilation, intravenous fluid therapy, pharmacotherapy using antibiotics, steroids, inotropes, sedatives, analgesics, anticoagulant and antipyretics, dialysis, endovascular procedures and organ transplantation. Although these interventions may improve the acute phase of the illness, in a majority of cases they fail to treat the latent pathophysiological changes causing organ failure [11, 12].

The evolution of organ failure in individual body systems occurs through the altered transcription of thousands of regulatory genes involved in immunity and metabolic-bioenergetic pathways leading to disruption of fundamental cellular processes or activation of cellular death pathways, including apoptosis, necrosis and autophagy in parenchymal and nonparenchymal tissues $[13,14]$.

Endothelial dysfunction has been described as a major predisposing factor in pathophysiology of most critical illnesses. Homeostasis in cardiovascular system, lung, kidney, brain and most major body systems is maintained by vascular endothelium $[15,16]$. In the arterial vasculature, endothelial impairment contributes to the pathogenesis of complex disease processes such as atherosclerosis and its life-threatening complications, myocardial infarction and stroke [17, 18]. In severe infections, the complex interactions between the infecting organisms and the host immune leading to endothelial dysfunction are poorly understood [19]. It has been suggested that in sepsis, the interaction between endothelial cells and the cellular immune system affects the integrity of the endothelium. In most pathological conditions this effect can be further amplified when the coagulation and complement systems are activated, resulting in vasoregulatory dysfunction, microaggregation impairment and atherosclerotic plaque formation, reducing microvascular flow, creating local ischemia and hypoxia. As a consequence, this may impair cellular respiration and permeability of the endothelium, which enables the inflammatory cells and products to leave the circulation forming generalized edema [20]. It should be emphasized that hypoxia itself is a leading cause of cell death via apoptosis, resulting in organ failure. Different mechanisms have been proposed for hypoxia-induced apoptosis such as enhanced permeability of the inner mitochondrial membrane leading to deprivation of mitochondrial derived Adenosine triphosphate (ATP) and apoptosis mediated by reactive oxygen species (ROS) formation [21, 22]. Overall, there are similarities in underlying mechanisms in causing acute and chronic dysfunction in individual organs, however, the molecular basis of organ failure is more complex and requires further investigation.

\section{Mesenchymal Stromal/Stem Cells (MSCs)}

MSCs are multipotent adult stromal cells with the capacity to differentiate into multiple cell types such as osteoblasts, adipocytes, and chondroblasts [23]. MSCs can be isolated from different sources including bone marrow, adipose tissue, umbilical cord, peripheral blood, heart and various other organs [24]. MSCs are adherent to plastic in standard culture conditions, express the surface molecules CD105, CD73 and CD90, but lack the expression of CD45, CD34, CD14, CD11b, CD79alpha, CD19 and HLA-DR [25]. Allogeneic MSCs are especially attractive due to their potential to provide an 'offthe-shelf' therapeutic cell product for immediate infusion to patients with acute critical illness and organ dysfunction. This is favoured by biological characteristics including convenient isolation, rapid expansion in culture and minimal immunogenicity. In terms of their low immunogenicity, the question has been raised as to whether these cells are immune evasive rather than immune privileged [26]. The prevailing dogma has been that allogeneic MSCs are immune privileged, but few studies have assessed and controlled for matched or mismatched major histocompatibility complex (MHC) molecule expression in vivo. While a few published studies that controlled for MHC donor and recipient haplotypes suggest that adult MHC-mismatched MSCs may in fact not be immune privileged, a systematic review of MSC-based clinical trials that described over 1000 patients who had received MSCs for various clinical conditions including ischemic stroke, Crohn's disease, cardiomyopathy, myocardial infarction, graft versus host disease, as well as healthy volunteers found these cells to be safe for human administration. Specifically, meta-analysis of the randomized clinical trials included did not detect an association between acute infusional toxicity, organ system complications, infection, death, malignancy or evidence of 
significant immune dysregulation. There however was a significant association between MSCs and transient fever [27].

MSCs are purported to home to the wounded or damaged tissue sites [28]. This is driven by the expression of 'homing factors', for example, stromal cell derived factor 1/CXCR4 pathway that can mediate traffic of MSCs to ischemic or hypoxic tissues [29], or by CD44 expressed on MSCs that may interact with hyaluronic acid where interstitial matrices are exposed after an injury [30]. When administered intravenously, MSCs become entrapped in the capillary beds - primarily in the lung and liver [31]. The biological meaning of MSC entrapment is not clear $[32,33]$. As a therapeutic strategy for acute critical illness, we and others have shown that enhanced anti-bacterial and pro-survival advantage does not depend on cell-cell contact as cell engraftment with differentiation [34, 35 ], trans-differentiation, or cell fusion are not required for therapeutic effect [36]. In fact, it was suggested that MSCs do not even have to be viable to confer a beneficial advantage [37].

The vast majority of infused MSCs reside transiently in the lungs, becoming undetectable within 96 h [38]. Currently, it has been suggested that MSC-derived paracrine mediators and extracellular vesicles (EVs) deliver effector molecules including mRNAs, miRNAs, DNA, proteins, and lipids that regulate function in recipient cells [39-41]. Indeed, EVs can account for many of the therapeutic effects of MSCs [42]. The number, size, and content of MSC- derived EVs vary based on the microenvironmental conditions [43, 44].

EVs are derived from different cellular compartments such as early endosomes and cell membrane and can be categorized into exosomes (30-150 nm) and large vesicles such as microvesicles (MVs) (50-1000 nm), apoptotic bodies (500$5000 \mathrm{~nm}$ ), or Golgi vesicles [45-47]. In the pulmonary vasculature, MSCs release EVs and mediators that have both local (pulmonary) and systemic effects. MSCs administered in preclinical models of pulmonary injury and sepsis release anti-inflammatory mediators [48-51] and EVs containing signaling-relevant nucleotides, proteins and possibly lipids [52].

The strong immunoregulatory properties of MSCs, affecting both adaptive and innate immune systems have been characterized in several studies [53]. MSC administration results in an overall modulation of the host transcriptional response, characterized by a down-regulation of inflammation and an up-regulation of genes involved in phagocytosis, bacterial killing [54]. MSC administration results in transcriptional reprogramming of the host response to injury and repair [55]. By modulating response in recipient cells, MSCs can change the activity of various immune cells like T-cells, B-cells, neutrophils, NK cells, dendritic cells and macrophages. In T-cells, MSCs suppress activation and proliferation; inhibit monocyte differentiation, and block proliferation of B-cells [56, 57]. MSCs also inhibit B lymphocyte proliferation via G0/G1 phase arrest [58, 59], leading to inhibition of antibody production [60]. An intriguing property of MSCs is their ability to enhance bacterial phagocytosis and killing [34, 48]. We have demonstrated that treatment with MSCs enhances gene expression related to antigen presentation and bacterial killing in sepsis model [34, 54, 61]. Moreover, it has been proposed that MSCs may be "educated" to enhance specific phenotypes [62] . MSC phenotype and the potential effect exerted on the immune system is dependent upon the microenvironment as MSCs may be induced to develop a pro- or an antiinflammatory phenotype [63]. Pro-inflammatory MSCs are associated with early stage infection and inflammation, such as through Toll Like Receptor 4 (TLR 4) activation by LPS. However, activation of TLR3 with poly I:C or dsDNA results in an alternative MSC phenotype characterized by secretion of immunosuppressive mediators [64]. Recent studies have suggested a role for macrophages in the reduction of inflammation and promotion of tissue repair [65]. MSCs secrete lipoxins, specialized proresolving lipid mediators that limit excessive inflammation, induce resolution, and protect from leukocyte-mediated tissue damage. Previous studies suggested that aspirin-triggered 15-epi-LXA4 induced neutrophil apoptosis and facilitates resolution of pulmonary inflammation [66]. In a murine model of LPS induced lung injury, a LXA4 receptor antagonist reversed the beneficial effect of MSCs on survival and pulmonary edema resorption. Thus, there are several mechanisms by which MSCs may improve host response during critical illness. Based on the pathophysiology and molecular basis of target disease and the goal of therapy, the therapeutic functions of MSCs may be modulated by performing appropriate genetic modifacations.

\section{Genetic Modification of Mesenchymal Stromal/Stem Cells}

Although, MSCs possess various favorable biological activities, the diseases-specific therapeutic efficacy and immunomodulatory properties of these cells and their derivatives such as EVs can be further optimised. Gene modification can improve the natural function of MSCs in different aspects such as tissue regeneration, repairing organ injury and immunemodulation [51]. These critical functions can be augmented by reprogramming MSCs via upregulation or downregulation of their native genes resulting in a controlled production of their own natural specific desired products such as pro/antiinflammatory mediators and cytokines, or by introducing critical foreign genes that modulate the therapeutic effects of MSCs or enable them to express non-native products for specific therapeutic applications $[67,68]$. In recent reports, a novel approach using MSCs as gene or drug delivery vehicles has been described, which emphasizes other potential application of genetically-modified MSCs [69, 70]. This can greatly broaden the spectrum of diseases for which MSCs could 
provide therapeutic benefits. Overall, gene modification may be applied to generate: 1 . Disease-specific potent MSCs with improved immunomodulatory or regenerative properties, 2 . MSCs as vehicles for gene delivery or manufacturing specific therapeutic proteins, 3. Loading of therapeutic cargo into MSC-derived extracellular vesicles (EVs) as potent therapeutic or vehicles for gene, mRNA and protein delivery.

Genetic modification of MSCs can be facilitated by different tools and techniques that introduce particular genes or sequences to the genomic content or tailor the native genetic material using molecular engineering techniques called "gene editing" [71].

Clustered Regularly Interspaced Short Palindromic Repeats (CRISPR)/Cas9 is a novel gene-editing technology in which, a complex made of Cas9 nuclease and a small guide RNA produces a target-specific break in the genome followed by insertion of a new sequence mediated by homologydirected repair that can be used to correct a gene mutation, introduction of a knock-in or knock out mutation or silencing of a specific gene [72]. CRISPR/Cas9 has been employed to some extent for gene editing of MSCs [73, 74]. The gene expression machinary can also be manipulated at the cytoplasmic level by RNA interference technology using siRNAs or microRNAs that inhibit the expression of messanger RNA of target genes in a sequence specific manner [75].

\section{Nucleic Acid Delivery Systems}

Delivery of therapeutic genes or sequences for genetic manipulation in target cells or tissues can be accomplished using viral and nonviral delivery systems with different characteristics, as discussed below:

\section{Viral Vectors}

Viral vectors are promising tools for nucleic acid delivery in pre-clinical and clinical applications. Almost $70 \%$ of clinical gene therapy trials around the world conducted are based the use of viral vectors such as lentiviral/retroviral, adenoviral and adeno-associated viral vectors [76]. Several fundamental features of viral vectors including high transduction efficiency and tropism for a broad range of target cells and tissues, high safety profile, and establishment of a long-term transgene expression have made them attractive systems for gene therapy. Drawbacks for therapeutic application of viral vectors include their immunogenicity, limited loading capacity and potential insertional mutagenesis described for integrating types [77, 78]. Among the different types of viral vectors, recombinant lentiviral vectors as a subgroup of retrovirus family have been the most frequently used systems due to the high tropism and transduction efficiency and stable expression of transgene in MSCs [79, 80]. Also, lentivectors have a high loading capacity which is a great advantage allowing transferring large genes (up to $8 \mathrm{~kb}$ ) into target cells/tissues. Furthermore, current generations of lentiviral vectors have a convincing safety record proven repeatedly in several analytical studies and clinical trials worldwide [81].

Adeno-Associated Viral (AAV) vectors with different serotypes have shown significant promise for gene therapy. The high transduction efficiency of these vectors in a broad range of target cells and tissues as well as their excellent safety profile and a minimal inflammatory toxicity have made them an attractive choice for gene therapy applications $[82,83]$. Although, AAVs suffer from a limited loading capacity for exogenous DNA (up to $4 \mathrm{~kb}$ ), overall, they are known as efficient gene therapy tools being employed in clinical applications [84]. Several studies have shown that AAV vectors can efficiently transduce MSCs $[85,86]$. Adenoviral vectors (AdVs) have long been used as efficient non-integrating gene therapy vectors that induce a transient gene expression in both dividing and quiescent cells [87]. AdVs offer an excellent safety profile and account for $>20 \%$ of all gene therapy trials worldwide. The immunogenic nature of AdVs has proved beneficial for the development of anticancer immunotherapies as well as vaccines, where the goal is inducing immunity against the cancer cells [88].

\section{Nonviral Delivery Systems}

Nonviral delivery systems such as plasmid DNA, DNA minicircles, nanoplasmids, liposomes and polymers have been extensively studied for gene delivery applications [89-91]. The main advantage of using nonviral vectors is their limited immunogenicity, enhanced biosafety and high loading capacity. However, the application of nonviral systems in gene therapy has been limited due to their low transfection efficiency and transient expression of the transgene [92]. Liposomes and polymers are among traditional nonviral delivery systems shown that transiently transfect MSCs [90, 93-95]. Minicircles are small DNA-based vectors lacking prokaryotic backbone sequences that are typically present in conventional plasmid vectors. When compared to traditional plasmid vectors, minicircles have demonstrated less toxicity and immunogenicity, higher transfection efficiency and longer transgene expression, in vitro and in vivo [90, 96-98]. A number of reports suggest that minicircles can efficiently and stably transfect MSCs [99, 100].

\section{Therapeutic Effects of Genetically Modified MSCs in Critical Illness}

The choice of the appropriate genetic modulation in cellularbased gene therapy is a critical determinant of the therapeutic outcomes, as the impact of such intervention will be directly observed in functionality and therapeutic effects of transplanted cells. Table 1 provides an overview of cell 


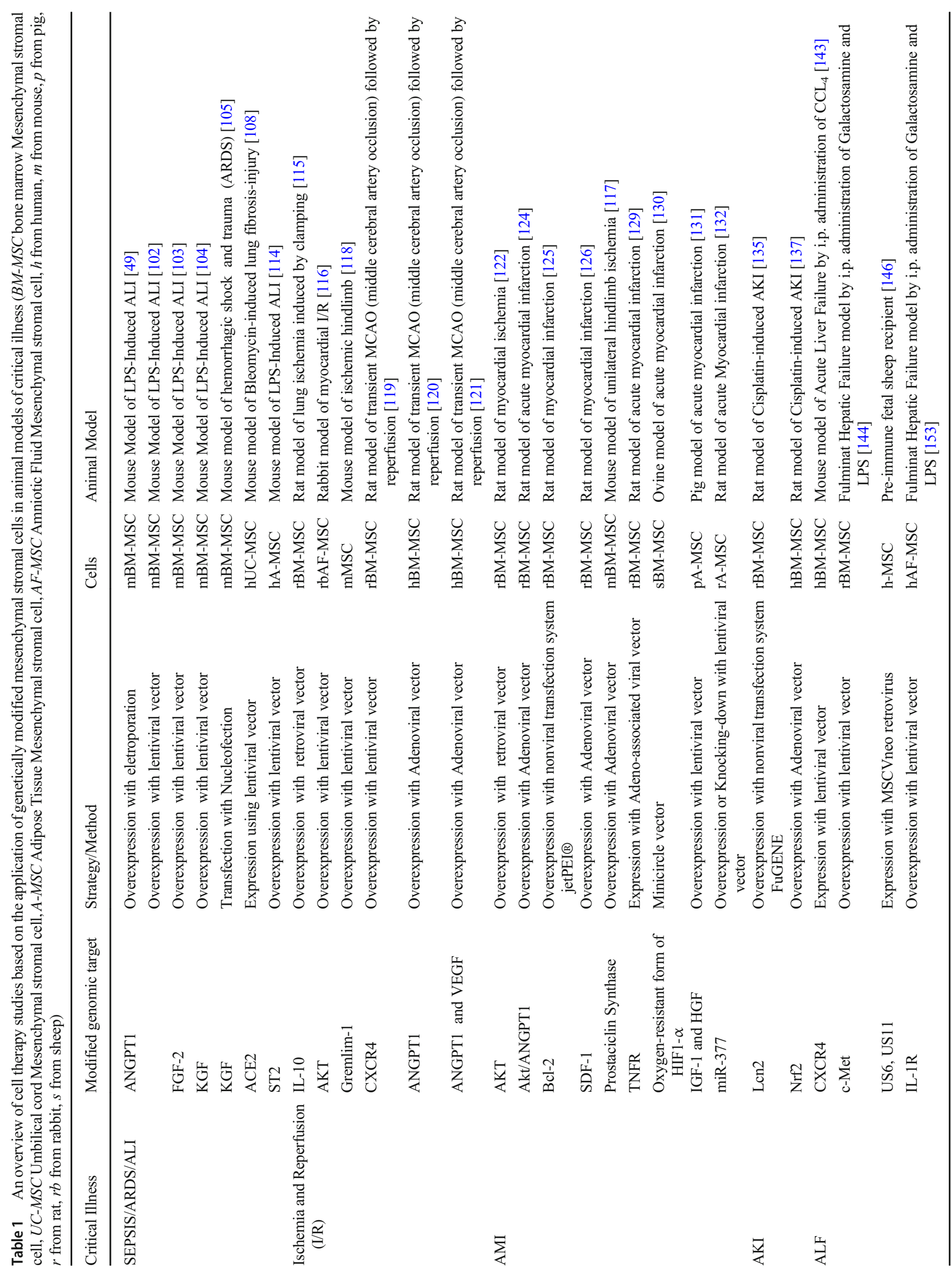


therapy studies based on application of genetically modified MSCs in animal models of critical illness.

\section{Genetically Modified MSCs for the Treatment of Acute Lung Injury}

Angiopoietin 1 (ANGPT1) is known as a vascular endothelial stabilization factor that mediates maturation of the vasculature and maintains their permeability. In two separate studies on LPS-induced acute lung injury mouse model $[49,101]$, the administration of ANGPT1-overexpressing bone marrow MSCs (BM-MSCs), modified by electroporation/plasmid or lentivectors, led to a much higher reduction in pulmonary inflammation and vascular endothelial permeability when compared to wild-type MSC treatment. It was noted that MSCs-ANGPT1 had a more potent therapeutic effect, not only by reducing extravasation of plasma proteins and inflammatory cells, but also by further reducing the levels of various inflammatory cytokines and chemokines including IFN $\gamma$, TNF- $\alpha$, IL-6, IL1 $\beta$ and Cxcl 2 in the bronchoalveolar lavage (BAL) fluid. Zhao et al. delivered BM-MSCs transduced with a lentivector carrying the gene for basic fibroblast growth factor (FGF2), an angiogenic factor, for the treatment of LPS-induced lung injury in mice. Treatment with FGF2modified MSCs attenuated the inflammatory response and vascular leakage as well as suppressed the expression of proinflammatory cytokines such as TNF- $\alpha$ and IL-6 in LPSinduced lung injury model [102].

Keratinocyte growth factor (KGF), also known as FGF-7, is a potent mitogenic factor for alveolar epithelial cells. It is known that the clinical effectiveness of exogenous recombinant (rh) KGF is limited due to rapid degradation. However, using a different approach, Chen et al. [103] transduced MSCs overexpressing KGF and showed the modified MSCs exerted their immunomodulatory functions via sustained expression of KGF in injured lung tissues, resulted in a significant alleviation of alveolar inflammation and permeability and improvement of lung injury. Recently, it was reported that the conditioned medium of KGF-modified MSCs resulted in similar therapeutic effects as MSC therapy [104].

The protective role of Angiotensin-converting enzyme 2 (ACE2) in acute lung injury was demonstrated previously $[105,106]$. Min et al. used a lentivector encoding for ACE2 and showed that treatment of a mouse model of bleomycininduced lung injury, with human umbilical cord-derived MSCs (UC-MSCs) overexpressing ACE2, led to efficient therapeutic effects by improving the inflammatory profile. Importantly, MSCs expressing ACE2 had a more robust therapeutic effect than application of recombinant ACE2 or naïve MSCs [107].

In a similar approach, He et al. [108] used BM-MSCs transduced with a lentivector overexpressing ACE2 and transplanted into wild type and ACE2 knockout mice following LPS-induced lung injury and showed that MSCACE2 efficiently alleviated lung injury at 24 and $72 \mathrm{~h}$ posttransplantation when compared to naïve MSCs.

Recent studies have investigated the therapeutic effects of MSCs in the novel coronavirus 2 (SARS-CoV-2)-induced ARDS and organ failure [109-111]. In a pilot trial, Leng et al. performed intravenous transplantation of ACE2overexpressing MSCs into seven patients with COVID-19 pneumonia. Two days after MSC administration, a significant improvement of pulmonary function and symptoms was observed in all patients. The results of this study show an increase in the number of regulatory $\mathrm{T}$ lymphocytes and dendritic cells (DCs), an increase in IL-10 and a decrease in TNF- $\alpha$ after MSC treatment [112].

The IL-33/IL-1 receptor-like-1 (ST2) axis has been suggested to function as an alarm system in lungs, which is released upon endothelial or epithelial cell damage [113]. Gonzalez et al. [114], generated adipose tissue-derived MSCs (A-MSCs) overexpressing soluble IL-1 receptor-like1 (sST2) using a lentiviral vector. Treatment of mouse LPSinduced lung injury model with these cells resulted in a decrease in lung airspace inflammation and vascular leakage, characterized by reductions in protein leakage, differential neutrophil counts, TNF- $\alpha$, IL-6, and macrophage inflammatory protein 2 in bronchoalveolar lavage fluid of treated animals. Lungs showed preserved alveolar architecture, absence of apoptosis, and minimal inflammatory cell infiltration.

\section{Genetically Modified MSCs for the Treatment of Acute Ischemia Reperfusion Injury}

Ischemia-reperfusion (IR) injury is a critical condition that may occur in the vasculature of different organs, mainly lung and heart. This pathologic condition is characterized in lung by nonspecific alveolar damage, edema formation, and hypoxemia. Manning et al., administered IL-10-overexpressing BM-MSCs as a delivery system for IL-10, to prevent lung IR injury in rats. They applied a retrovirus carrying IL-10 cDNA for genetic engineering of MSCs. It was shown that as early as $4 \mathrm{~h}$ post-IR injury, blood oxygenation was significantly improved in animals treated with MSC-IL-10 in comparison to untreated animals. Moreover, MSC-IL-10-treated animals had fewer CD4(+) and CD8(+) T cells in bronchoalveolar lavage fluid compared to untreated control animals [115].

In a study by Wang et al. [116], the cardioprotective effect of genetically modified MSCs was evaluated after ischemiareperfusion (I/R) injury in heart. In this study, amniotic fluidderived mesenchymal stromal cells (AF-MSCs) overexpressing Akt, a serine-threonine kinase involved in survival and proliferation of MSCs as well as in survival and cell cycling of cardiomyocytes, were transplanted into the ischemic myocardium of rabbits prior to reperfusion. Three weeks post- 
transplantation, a significant decrease in myocardial inflammation, ultrastructural damage and cardiomyocyte apoptosis as well as a marked augmentation in left ventricular function was observed in animals treated with AF-MSC-Akt when compared to control group.

Ishii et al. [117], assessed the therapeutic effects of genetically modified MSCs in a mouse model of critical limb ischemia (CLI) which is characterized by a markedly reduced blood-flow in the limb, due to severe arterial blockage. Using an adenoviral vector, they overexpressed the vasoregulatory protein, prostacyclin synthase (PGIS) in BM-MSCs and transplanted the mice after inducing hindlimb ischemia. It was shown that by administering PGIS-overexpressing MSCs they were able to obtain reperfusion of the ischemic limb within 7 days of inducing ischemia, suggesting enhanced proangiogenic function of genetically modified MSCs had a fundamental effect on outcomes. Moreover, in this report, MSC-induced overexpression of PGIS resulted in higher expression levels of the antiapoptotic mediators phosphorylated Akt and Bcl-2.

Gremlin1 (GREM-1) is an extracellular antagonist of the bone morphogenetic proteins (BMPs), acting as a regulator of growth, differentiation and development. GREM-1 has been identified as a novel proangiogenic factor. In a recent study by Xiang et al. [118], the therapeutic effects of BM-MSCs overexpressing GREM-1 was investigated in a mouse model of ischemic hindlimb. Transduction of MSCs with a lentivirus overexpressing GREM-1 showed enhanced survival when exposed to peroxide $\left(\mathrm{H}_{2} \mathrm{O}_{2}\right)$, attributed to enhanced in vivo survival of genetically modified MSCs and their effects on the viability of endothelial cells in the ischemic area.

$\mathrm{Yu}$ and colleagues took advantage of CXCR4 role in MSC chemotaxis and hypothesized that MSCs overexpressing CXCR4 can promote their own recruitment around the ischemic core. Using lentiviral vector, they generated rat MSCs overexpressing the CXCR4-eGFP fusion protein. They treated the animals following a left middle cerebral artery occlusion for $2 \mathrm{~h}$ and then reperfusion was performed. One week post treatment, there was an increased number of eGFPpositive cells surrounding the infarct areas in the CXCR4MSC group when compared to the naïve MSC group. Treatment with CXCR4-MSCs also resulted in an increase in the capillary vascular volume of the peri-infarct area, reduction in the volume of the cerebral infarction and improved neurological function when compared to control groups [119].

Kocsis's group used human BM-MSCs transduced with an adenoviral vector carrying a human Angiopoietin 1 (ANGPT1) cDNA, for the treatment of permanent middle cerebral artery occlusion (MCAO) in rats. They demonstrated that treatment with these cells presented a better outcome in terms of neovascularization and regional cerebral blood flow, and improved functional recovery in the treadmill stress test in comparison to naïve MSCs [120]. In a similar study, the same group expanded the gene modification strategy and transduced hBM-MSCs with adenoviral vectors carrying a human ANGPT1 gene and VEGF gene and investigated whether the combination of ANGPT1 and VEGF genemodified MSCs (ANGPT1-VEGF-hMSC) contributed further to functional recovery in a rat MCAO model. It was noticeable in the MRI and behavioral experiments that animals which received ANGPT1-VEGF-hMSCs showed the greatest structural-functional recovery when compared to all the other control groups [121].

\section{Genetically Modified MSCs for the Treatment of Acute Myocardial Injury}

In the case of MSC therapy for acute myocardial infarction (AMI), most of the applied genetic modification approaches were based on enhancing the survival, migration and retention properties of MSCs as well as reprograming them to produce angiogenic and regenerative factors. Mangi et al. [122] overexpressed Akt in BM-MSCs using a retroviral vector followed by transplantation of these cells into the ischemic rat myocardium. This was associated with a remarkable reduction of infarct size and myocardial remodeling as well as improved left ventricular function. Importantly, the hypothesis that MSCs differentiate into cardiomyocytes was challenged by new reports, indicating that the therapeutic function of MSCs was due to the enhanced production of antiinflammatory as well as pro-repair factors [123]. Shujia et al. [124], improved the duration of the beneficial effects of MSC therapy up to 3 months by co-transducing MSCs with two adenoviral vectors encoding for Akt or the pro-angiogenic protein Angiopoietin 1 in a rat AMI model.

In a study by Li et al. [125], Bcl-2, a pro-survival antiapoptotic gene was overexpressed in rat BM-MSCs using polymeric delivery system, polyethylenimine (PEI). Intracardiac injection of transfected MSCs in a rat model of AMI resulted in reduction of infarct size and a better left ventricular function compared to control group. Furthermore, this study demonstrated that the therapeutic effects of Bcl-2-overexpressing MSCs was partly due to an increase in vascular endothelial growth factor (VEGF). Also, overexpression of Bcl-2 enhanced the in vivo survival of MSCs.

Stromal-derived factor-1 alpha (SDF-1alpha) plays an important cardioprotective role by homing of stem cells to the injured heart tissue [126]. Tang et al. [127], overexpressed SDF- $1 \alpha$ in MSCs using an adenoviral vector, followed by intramyocardial transplantation in a rat model of myocardial infarction. Four weeks following transplantation, these investigators were able to show reduced infarct size and fibrosis, greater vascular density and thicker left ventricular wall in the Ad-SDF-MSC group compared to rats treated with naïve MSCs. Moreover, it was reported that transplanted MSCs were partly positive for the cardiac marker troponin- $\mathrm{T}$, 
suggesting that transplanted MSCs can differentiate into cardiomyocytes. In a follow up study by the same group, dual overexpression of VEGF and SDF- $1 \alpha$ in MSCs using adenoviral vectors demonstrated additive therapeutic benefits in experimental model of AMI [128].

Bao et al. [129], investigated the therapeutic effect of BMMSCs overexpressing tumor necrosis factor receptor (TNFR), mediated by a recombinant AAV vector, in a rat model of AMI. It was demonstrated that treatment with genetically modified MSCs improved cardiac inflammation and left ventricular function 2 weeks post-MI. This therapeutic effect was attributed to the anti-apoptotic and anti-inflammatory function of TNFR-overexpressing MSCs.

Hypoxia-inducible factor $1-\alpha$ (HIF $1-\alpha)$ is known to upregulate various cardioprotective genes during ischemia. Hnatiuk et al. [130] used a minicircle vector encoding a stable, oxygenresistant form of HIF1- $\alpha$ for transfection of BM-MSCs followed by intramyocardial delivery of the cells in a sheep model of AMI. Over a 2-month follow-up study, it was shown that treatment with modified MSCs reduced infarct size and improved LV systolic performance compared to naïve MSCs, attributed to increased neovascularization and cardioprotective effects induced by HIF1-mediated overexpression of paracrine factors and enhanced retention of injected cells.

In a study by Gomez et al. [131], pig MSCs derived from adipose tissue were transduced with lentivectors encoding for insulin-like growth factor 1 (IGF-1) or hepatocyte growth factor (HGF). These cells were used to improve cardiac function in a porcine model of intramyocardial transplantation. Overexpression of either IGF-1 or HGF improved left ventricular ejection fraction (LVEF), cardiac output, and stroke volume, and reduction in heart rate and infarction size compared to naïve MSCs.

Wen and colleagues [132], searched for the most important microRNAs associated with angiogenic properties in MSCs. Using microRNA microarray analysis, they found that the expression of microRNA-377 was reduced in hypoxiatreated MSCs. The group further reported that VEGF is a direct target of microRNA-377. Using lentivectors, they knocked-down miR-377 in MSCs and administered these cells in a rat model of AMI. Four weeks after transplantation of miR-377 depleted MSCs into the infarcted rat hearts, the vessel density was increased in the heart, and this was accompanied by reduced fibrosis and improved myocardial function due to promotion of MSC-induced angiogenesis in the infarcted myocardium.

\section{Genetically Modified MSCs for the Treatment of Acute Kidney Injury}

Recent studies capitalized on the application of genetically modified MSCs for the treatment of Acute kidney injury (AKI) $[133,134]$. In a recent study by Roudkenar et al.
[135], overexpression of Lipocalin-2 (Lcn2) in MSCs enhanced their therapeutic effects in a cisplatin-induced AKI rat model. Lcn2, a neutrophil gelatinase-associated lipocalin, is a secretory protein discovered in neutrophils which accumulates in blood and urine after acute kidney injury due to bacterial infection [136]. Overexpression of Lcn2 in MSCs using FuGENE transfection reagent efficiently enhanced the therapeutic properties of these cells leading to improvement in renal function. Treatment with MSC-Lcn2 resulted in upregulation of HGF, IGF, FGF and VEGF growth factors following cisplatin-induced AKI. In addition, a reduction in molecular biomarkers of kidney injury such as KIM-1 and Cystatin $\mathrm{C}$ and elevation of the markers of proximal tubular epithelium such as AQP-1 and CK18 was observed.

In a study by Mohammadzadeh et al. [137], overexpression of nuclear factor erythroid-2 related factor 2 (Nrf2), a critical cytoprotective transcription factor, in BM-MSCs protected rats against $\mathrm{AKI}$ by restoring renal tubule structure and improving renal function. Additionally, Nrf2-MSCs were resistant to apoptosis and produced higher amount of growth factors.

\section{Genetically Modified MSCs for the Treatment of Acute Liver Injury}

Acute liver failure (ALF) is a clinical syndrome characterized by hepatocellular necrosis observed after acute injuries due to assaults such as viral infections, hepatotoxic drugs, autoimmune responses and veno-occlusive disease. The only definitive treatment for ALF is liver transplantation, which is limited because of financial aspects, shortage of donor, and immunosuppression-related complications [138].

The therapeutic function of genetically modified MSCs in acute liver injuries are partially based on their regenerative properties and differentiation into hepatocyte-like cells (HLCs) [139-142]. Therefore, the key element for better therapeutic outcomes in liver injury is an efficient targeted delivery and homing of MSCs in the injured area.

$\mathrm{Hu}$-Cheng Ma and colleagues [143] hypothesized that overexpression of CXCR4 (chemokine CXC receptor 4), a receptor for SDF-1 $\alpha$ involved in MSC homing - would enhance the engraftment of MSCs in the injured liver and improve liver regeneration. In this study, liver injury was induced using hepatotoxic chemical carbon tetra chloride CCL4. Both in vitro and in vivo experiments showed that CXCR4 MSCs present better migration capability than nullMSCs toward the injured area and prevented cell death in hepatocytes. In vivo fluorescence imaging demonstrated the presence of CXCR4 MSCs in liver at days 1 and 5 after liver injury. Moreover, CXCR4 MSC group presented a longer lifetime and better liver function and histology.

In a study by Wang et al. [144], in order to enhance the migration ability and homing properties of bone marrow 
MSCs in acute liver injury, c-Met, a member of tyrosine protein kinase family - was overexpressed using a lentivector. Hepatocyte growth factor (HGF) is known as the ligand of c-Met and the HGF/c-Met signaling pathway is considered to play an important role in the homing ability of MSCs to the liver [145]. In this study, in vitro assays showed that cMet-MSCs had a higher migration activity in comparison with control MSCs. Transplantation of c-Met-MSCs into rats with ALF resulted in an improved homing ability of the MSCs to the injured liver, ameliorated liver injury with reduced hepatic activity index (HAI) scores and enhanced survival.

Another approach to improve the success of MSC therapy is to make MSCs look as invisible as possible to the recipient's immune system. Soland and colleagues [146], genetically engineered human MSCs using MSCVneo retrovirus to express human cytomegalovirus proteins that are known to downregulate HLA-I expression (US2, US3, US6 and US11). After this genetic modification, they tested if these MSCs were protected from cytotoxic $\mathrm{T}$ lymphocyte and Natural killer cell attack. From the 4 different proteins they tested, only US6 and US11 reduced HLA-I expression. This reduction in HLA-1 expression was accompanied by a decrease in human and sheep mononuclear cell proliferation after a mixed lymphocyte reaction. Transplantation of MSCUS6 or MSC-US1 1 cells into pre-immune fetal sheep resulted in an increased liver engraftment when compared to control MSCs.

Poor in vivo cell viability of MSCs has been a limiting factor for their therapeutic effects [147, 148]. In order to make MSCs more resistant to apoptosis and enhance their in vivo survival, Zhou et al. overexpressed Akt1 - a pro-survival signal protein - in MSCs. The in vivo survival and hepatoprotective effects of Akt1-MSCs was investigated after transplantation into a rat model of acute liver injury induced by concanavalin A. When compared to control MSC groups, a higher survival rate and significantly lower serum AST, ALT, TNF- $\alpha$ and IFN- $\gamma$ levels and less histopathological abnormalities was observed in Akt1-MSCs treated animals. In addition, Akt1-MSCs treated mice had significantly higher serum concentrations of IL-10, vascular endothelial growth factor (VEGF) and hepatocyte growth factor (HGF).

Fulminant hepatic failure (FHF) is a lethal inflammatory liver disease with elevated serum levels of immunoinflammatory cytokines like IL-1, TNF, IL-6 and IL-8 [149, 150]. Uncontrolled hepatic immunoactivation has been proposed as the primary pathological mechanism of FHF [151]. IL-1Ra is a cytokine member of the IL-1 family known to prevent biological response to IL-1 by competing for its receptor. IL-1Ra presents hepato-protective effects [149] and play an anti-inflammatory role in acute and chronic inflammation [152]. Zheng and collaborators tested whether IL-1Ra overexpressing MSCs could protect injured livers in a rat FHF model. They used a lentivector to overexpress IL-1Ra in AF-MSCs and demonstrated that treatment of a rat model of FHF with these cells prevented liver failure and improved survival. The presence of engrafted cells and their progeny in the injured livers was shown using Fluorescent imaging [153].

\section{Concluding Remarks}

MSCs possess strong regenerative, pro-inflammatory, antiinflammatory and drug delivery properties. These features introduce MSCs as attractive cell-based therapeutics for critical medical conditions with inflammatory basis such as sepsis, ARDS, ALI, AKI, ALF, AMI and ischemia. Several studies based on experimental models of critical illness, have demonstrated that proper genetic modifications can enhance the therapeutic potency of MSCs in terms of improvement in mortality and morbidity. Genetic manipulations in MSCs can be mediated by advanced techniques and delivery systems, mainly gene therapy viral vectors, in order to efficiently induce expression, up-regulation or down-regulation of specific genes or pathways. Clinical translation of advances in genetically engineered MSCs requires detailed investigations on the safety and potency of each strategy in short- and long-term cell therapy studies in clinically relevant animal models of critical illness as reviewed in this report.

Authors' Contributions Conceptualization/original draft preparation: Amir Khashayar Varkouhi.

Writing-references and preparation of the table: Ana Paula Teixeira Monteiro.

Review and editing: James N. Tsoporis, Shirley H. J. Mei, Duncan J. Stewart.

Review, editing and supervision: Claudia C. dos Santos.

\section{Compliance with Ethical Standards}

Conflict of Interest The authors declare that they have no conflict of interest.

\section{References}

1. Umegaki, T., Ikai, H., \& Imanaka, Y. (2011, 27). The impact of acute organ dysfunction on patients' mortality with severe sepsis. Journal of Anaesthesiology Clinical Pharmacology, (2), 180-184. https://doi.org/10.4103/0970-9185.81816 PubMed PMID: 21772676 ; PubMed Central PMCID: PMCPMC3127295.

2. Terblanche, M., Kruger, P., di Gangi, S., Gearay, S., Gilfeather, L., Ferguson, N. D., et al. (2012). Risk factors for acute organ failure in intensive care unit patients who receive respiratory support in the absence of non-respiratory organ failure: An international prospective cohort study. Critical Care, 16(2), R61. https:// doi.org/10.1186/cc11306 PubMed PMID: 22512834; PubMed Central PMCID: PMCPMC3681390.

3. Kaneki, M. (2017). Metabolic inflammatory complex in sepsis: Septic cachexia as a novel potential therapeutic target. Shock, 
48(6), 600-609. https://doi.org/10.1097/SHK. 0000000000000906.

4. Rossaint, J., \& Zarbock, A. (2015). Pathogenesis of multiple organ failure in sepsis. Critical Reviews in Immunology, 35(4), 277-291.

5. Shankar-Hari, M., Phillips, G. S., Levy, M. L., Seymour, C. W., Liu, V. X., Deutschman, C. S., et al. (2016). Developing a new definition and assessing new clinical criteria for septic shock: For the third International consensus definitions for sepsis and septic shock (sepsis-3). JAMA, 315(8), 775-787. https://doi.org/10. 1001/jama.2016.0289 PubMed PMID: 26903336; PubMed Central PMCID: PMCPMC4910392.

6. Paoli, C. J., Reynolds, M. A., Sinha, M., Gitlin, M., \& Crouser, E. (2018). Epidemiology and costs of sepsis in the United States-an analysis based on timing of diagnosis and severity level. Critical Care Medicine, 46(12), 1889-1897. https://doi.org/10.1097/ CCM.0000000000003342 PubMed PMID: 30048332; PubMed Central PMCID: PMCPMC6250243.

7. Gotts, J. E., \& Matthay, M. A. (2016). Sepsis: Pathophysiology and clinical management. British Medical Journal, 353, i1585. Epub 2016/05/23. https://doi.org/10.1136/bmj.i1585.

8. McIntyre, L. A., Stewart, D. J., Mei, S. H. J., Courtman, D., Watpool, I., Granton, J., et al. (2018). Cellular immunotherapy for septic shock. A phase I clinical trial. American Journal of Respiratory and Critical Care Medicine, 197(3), 337-347. https://doi.org/10.1164/rccm.201705-1006OC.

9. Alonso, A., Ebert, A. D., Kern, R., Rapp, S., Hennerici, M. G., \& Fatar, M. (2015). Outcome predictors of acute stroke patients in need of intensive care treatment. Cerebrovascular Diseases, 40(1-2), 10-17. Epub 2015/05/27. https://doi.org/10.1159/ 000430871.

10. Jiménez-Candil, J., Díaz-Castro, Ó., Barrabés, J. A., de la García Villa, B., Bodí Peris, V., López Palop, R., et al. (2013). Update on ischemic heart disease and critical care cardiology. Revista Española de Cardiología, 66(3), 198-204. Epub 2013/01/24. https://doi.org/10.1016/j.rec.2012.10.015.

11. Mer, M., Schultz, M. J., \& Adhikari, N. K. (2017). European Society of Intensive Care Medicine (ESICM) Global Intensive Care Working Group and the Mahidol-Oxford Research Unit (MORU) B, T.ailand. Core elements of general supportive care for patients with sepsis and septic shock in resource-limited settings. Intensive Care Medicine, 43(11), 1690-1694. https://doi. org/10.1007/s00134-017-4831-z Epub 2017/06/15, PubMed PMID: 28620804; PubMed Central PMCID: PMCPMC5633616.

12. Naib, T., Lahewala, S., Arora, S., \& Gidwani, U. (2015). Palliative care in the cardiac intensive care unit. The American Journal of Cardiology, 115(5), 687-690. Epub 2014/12/18. https://doi.org/ 10.1016/j.amjcard.2014.12.023.

13. Singer, M. (2017). Critical illness and flat batteries. Critical Care, 21(Suppl 3), 309. https://doi.org/10.1186/s13054-017-1913-9 Epub 2017/12/28. PubMed PMID: 29297363; PubMed Central PMCID: PMCPMC5751585.

14. Hotchkiss, R. S., Monneret, G., \& Payen, D. (2013). Sepsisinduced immunosuppression: from cellular dysfunctions to immunotherapy. Nature Reviews Immunology, 13(12), 862-874. https:// doi.org/10.1038/nri3552 Epub 2013/11/15. PubMed PMID: 24232462; PubMed Central PMCID: PMCPMC4077177.

15. Coletta, C., Módis, K., Oláh, G., Brunyánszki, A., Herzig, D. S., Sherwood, E. R., et al. (2014). Endothelial dysfunction is a potential contributor to multiple organ failure and mortality in aged mice subjected to septic shock: preclinical studies in a murine model of cecal ligation and puncture. Critical Care, 18(5), 511. https://doi. org/10.1186/s13054-014-0511-3 Epub 2014/09/16. PubMed PMID: 25223540; PubMed Central PMCID: PMCPMC4177582.

16. Roquer, J., Segura, T., Serena, J., \& Castillo, J. (2009). Endothelial dysfunction, vascular disease and stroke: The
ARTICO study. Cerebrovascular Diseases, 27(Suppl 1), 25-37. Epub 2009/04/03. https://doi.org/10.1159/000200439.

17. Mudau, M., Genis, A., Lochner, A., \& Strijdom, H. (2012). Endothelial dysfunction: The early predictor of atherosclerosis. The Cardiovascular Journal of Africa, 23(4), 222-231. https:// doi.org/10.5830/CVJA-2011-068 PubMed PMID: 22614668; PubMed Central PMCID: PMCPMC3721957.

18. Gimbrone, M. A., \& García-Cardeña, G. (2016). Endothelial cell dysfunction and the pathobiology of atherosclerosis. Circulation Research, 118(4), 620-636. https://doi.org/10.1161/ CIRCRESAHA.115.306301 PubMed PMID: 26892962; PubMed Central PMCID: PMCPMC4762052.

19. Boisramé-Helms, J., Kremer, H., Schini-Kerth, V., \& Meziani, F. (2013). Endothelial dysfunction in sepsis. Current Vascular Pharmacology, 11(2), 150-160.

20. Ince, C., Mayeux, P. R., Nguyen, T., Gomez, H., Kellum, J. A., Ospina-Tascón, G. A., et al. (2016). The endothelium in sepsis. Shock, 45(3), 259-270. https://doi.org/10.1097/SHK. 0000000000000473 PubMed PMID: 26871664; PubMed Central PMCID: PMCPMC5281063.

21. Berger, M. M., \& Grocott, M. P. W. (2017). Facing acute hypoxia: From the mountains to critical care medicine. British Journal of Anaesthesia, 118(3), 283-286. https://doi.org/10.1093/bja/ aew407.

22. Kiers, H. D., Scheffer, G. J., van der Hoeven, J. G., Eltzschig, H. K., Pickkers, P., \& Kox, M. (2016). Immunologic consequences of hypoxia during critical illness. Anesthesiology, 125(1), 237249. https://doi.org/10.1097/ALN.0000000000001163 PubMed PMID: 27183167; PubMed Central PMCID: PMCPMC5119461.

23. Kim, H. J., \& Park, J. S. (2017). Usage of human mesenchymal stem cells in cell-based therapy: Advantages and disadvantages. Development \& Reproduction, 21(1), 1-10. https://doi.org/10. 12717/DR.2017.21.1.001 Epub 2017/03/31. PubMed PMID: 28484739; PubMed Central PMCID: PMCPMC5409204.

24. Hass, R., Kasper, C., Böhm, S., \& Jacobs, R. (2011). Different populations and sources of human mesenchymal stem cells (MSC): A comparison of adult and neonatal tissue-derived MSC. Cell Communication and Signaling, 9, 12. https://doi.org/ 10.1186/1478-811X-9-12 Epub 2011/05/14. PubMed PMID: 21569606; PubMed Central PMCID: PMCPMC3117820.

25. Dominici, M., Le Blanc, K., Mueller, I., Slaper-Cortenbach, I., Marini, F., Krause, D., et al. (2006). Minimal criteria for defining multipotent mesenchymal stromal cells. The International Society for Cellular Therapy position statement. Cytotherapy, 8(4), 315317. https://doi.org/10.1080/14653240600855905.

26. Ankrum, J. A., Ong, J. F., \& Karp, J. M. (2014). Mesenchymal stem cells: Immune evasive, not immune privileged. Nature Biotechnology, 32(3), 252-260. https://doi.org/10.1038/nbt.2816 Epub 2014/02/23. PubMed PMID: 24561556; PubMed Central PMCID: PMCPMC4320647.

27. Lalu, M. M., McIntyre, L., Pugliese, C., Fergusson, D., Winston, B. W., Marshall, J. C., et al. (2012). Safety of cell therapy with mesenchymal stromal cells (SafeCell): A systematic review and meta-analysis of clinical trials. PLoS One, 7(10), e47559. https:// doi.org/10.1371/journal.pone.0047559 Epub 2012/10/25. PubMed PMID: 23133515; PubMed Central PMCID: PMCPMC3485008.

28. Karp, J. M., \& Leng Teo, G. S. (2009). Mesenchymal stem cell homing: The devil is in the details. Cell Stem Cell, 4(3), 206-216. https://doi.org/10.1016/j.stem.2009.02.001.

29. Honczarenko, M., Le, Y., Swierkowski, M., Ghiran, I., Glodek, A. M., \& Silberstein, L. E. (2006). Human bone marrow stromal cells express a distinct set of biologically functional chemokine receptors. Stem Cells, 24(4), 1030-1041. Epub 2005/10/27. https://doi. org/10.1634/stemcells.2005-0319. 
30. Zhu, H., Mitsuhashi, N., Klein, A., Barsky, L. W., Weinberg, K., Barr, M. L., Demetriou, A., \& Wu, G. D. (2006). The role of the hyaluronan receptor CD44 in mesenchymal stem cell migration in the extracellular matrix. Stem Cells, 24(4), 928-935. Epub 2005/11/23. https://doi.org/10.1634/stemcells.2005-0186.

31. Gao, J., Dennis, J. E., Muzic, R. F., Lundberg, M., \& Caplan, A. I. (2001). The dynamic in vivo distribution of bone marrow-derived mesenchymal stem cells after infusion. Cells, Tissues, Organs, 169(1), 12-20. https://doi.org/10.1159/000047856.

32. Weiss, D. J., Bates, J. H. T., Gilbert, T., Liles, W. C., Lutzko, C., Rajagopal, J., \& Prockop, D. J. (2013). Stem cell conference report: Stem cells and cell therapies in lung biology and diseases. Annals of the American Thoracic Society, 10, 25-44.

33. Matthay, M. A., Anversa, P., Bhattacharya, J., Burnett, B. K., Chapman, H. A., Hare, J. M., et al. (2013). Cell therapy for lung diseases. Report from an NIH-NHLBI workshop, November 1314, 2012. The American Journal of Respiratory and Critical Care Medicine, 188(3), 370-375. https://doi.org/10.1164/rccm. 201303-0522WS PubMed PMID: 23713908; PubMed Central PMCID: PMCPMC3778734.

34. Mei, S. H., Haitsma, J. J., Dos Santos, C. C., Deng, Y., Lai, P. F., Slutsky, A. S., et al. (2010). Mesenchymal stem cells reduce inflammation while enhancing bacterial clearance and improving survival in sepsis. American Journal of Respiratory and Critical Care Medicine, 182(8), 1047-1057. Epub 2010/06/17. https://doi. org/10.1164/rccm.201001-0010OC.

35. Matthay, M. A., Goolaerts, A., Howard, J. P., \& Lee, J. W. (2010). Mesenchymal stem cells for acute lung injury: Preclinical evidence. Critical Care Medicine, 38(10 Suppl), S569-S573. https://doi.org/10.1097/CCM.0b013e3181f1ffld PubMed PMID: 21164399; PubMed Central PMCID: PMCPMC3580946.

36. Deng, H., Sun, C., Sun, Y., Li, H., Yang, L., Wu, D., et al. (2018. Epub 2018/05/21). Lipid, protein, and microRNA composition within mesenchymal stem cell-derived exosomes. Cell Reprogram. https://doi.org/10.1089/cell.2017.0047.

37. Luk, F., de Witte, S. F., Korevaar, S. S., Roemeling-van Rhijn, M., Franquesa, M., Strini, T., et al. (2016). Inactivated mesenchymal stem cells maintain immunomodulatory capacity. Stem Cells and Development, 25(18), 1342-1354. https://doi.org/10.1089/scd. 2016.0068.

38. de Witte, S. F. H., Luk, F., Sierra Parraga, J. M., Gargesha, M., Merino, A., Korevaar, S. S., Shankar, A. S., O’Flynn, L., Elliman, S. J., Roy, D., Betjes, M. G. H., Newsome, P. N., Baan, C. C., \& Hoogduijn, M. J. (2018). Immunomodulation by therapeutic mesenchymal stromal cells (MSC) is triggered through phagocytosis of MSC by monocytic cells. Stem Cells, 36(4), 602-615. Epub 2018/02/01. https://doi.org/10.1002/stem.2779.

39. Wang, L., Gu, Z., Zhao, X., Yang, N., Wang, F., Deng, A., Zhao, S., Luo, L., Wei, H., Guan, L., Gao, Z., Li, Y., Wang, L., Liu, D., \& Gao, C. (2016a). Extracellular vesicles released from human umbilical cord-derived mesenchymal stromal cells prevent lifethreatening acute graft-versus-host disease in a mouse model of allogeneic hematopoietic stem cell transplantation. Stem Cells and Development, 25(24), 1874-1883. https://doi.org/10.1089/scd. 2016.0107.

40. Zulueta, A., Colombo, M., Peli, V., Falleni, M., Tosi, D., Ricciardi, M., Baisi, A., Bulfamante, G., Chiaramonte, R., \& Caretti, A. (2018). Lung mesenchymal stem cells-derived extracellular vesicles attenuate the inflammatory profile of cystic fibrosis epithelial cells. Cellular Signalling, 51, 110-118. https://doi. org/10.1016/j.cellsig.2018.07.015.

41. Zheng, G., Huang, R., Qiu, G., Ge, M., Wang, J., Shu, Q., \& Xu, J. (2018). Mesenchymal stromal cell-derived extracellular vesicles: Regenerative and immunomodulatory effects and potential applications in sepsis. Cell and Tissue Research, 374, 1-15. https://doi. org/10.1007/s00441-018-2871-5.
42. Lee, C., Mitsialis, S. A., Aslam, M., Vitali, S. H., Vergadi, E., Konstantinou, G., et al. (2012). Exosomes mediate the cytoprotective action of mesenchymal stromal cells on hypoxiainduced pulmonary hypertension. Circulation, 126(22), 26012611. https://doi.org/10.1161/CIRCULATIONAHA.112.114173 PubMed PMID: 23114789; PubMed Central PMCID: PMCPMC3979353.

43. de Witte, S. F. H., Merino, A. M., Franquesa, M., Strini, T., van Zoggel, J. A. A., Korevaar, S. S., et al. (2017). Cytokine treatment optimises the immunotherapeutic effects of umbilical cordderived MSC for treatment of inflammatory liver disease. Stem Cell Research \& Therapy, $(8,1), 140$. https://doi.org/10.1186/ s13287-017-0590-6 PubMed PMID: 28595619; PubMed Central PMCID: PMCPMC5465593.

44. Anderson, J. D., Johansson, H. J., Graham, C. S., Vesterlund, M., Pham, M. T., Bramlett, C. S., Montgomery, E. N., Mellema, M. S., Bardini, R. L., Contreras, Z., Hoon, M., Bauer, G., Fink, K. D., Fury, B., Hendrix, K. J., Chedin, F., el-Andaloussi, S., Hwang, B., Mulligan, M. S., Lehtiö, J., \& Nolta, J. A. (2016). Comprehensive proteomic analysis of mesenchymal stem cell exosomes reveals modulation of angiogenesis via nuclear factor-KappaB signaling. Stem Cells, 34(3), 601-613. https://doi.org/10.1002/stem.2298.

45. Fatar, M., Stroick, M., Griebe, M., Marwedel, I., Kern, S., Bieback, K., Giesel, F. L., Zechmann, C., Kreisel, S., Vollmar, F., Alonso, A., Back, W., Meairs, S., \& Hennerici, M. G. (2008). Lipoaspirate-derived adult mesenchymal stem cells improve functional outcome during intracerebral hemorrhage by proliferation of endogenous progenitor cells stem cells in intracerebral hemorrhages. Neuroscience Letters, 443(3), 174-178. Epub 2008/08/05. https://doi.org/10.1016/j.neulet.2008.07.077.

46. Doyle, L. M., \& Wang, M. Z. (2019). Overview of Extracellular Vesicles, Their Origin, Composition, Purpose, and Methods for Exosome Isolation and Analysis. Cells, 8(7). https://doi.org/10. 3390/cells8070727 Epub 2019/07/15. PubMed PMID: 31311206; PubMed Central PMCID: PMCPMC6678302.

47. Roy, S., Lin, H. Y., Chou, C. Y., Huang, C. H., Small, J., Sadik, N., et al. (2019). Navigating the landscape of tumor extracellular vesicle heterogeneity. The International Journal of Molecular Sciences, 20(6). https://doi.org/10.3390/ijms20061349 Epub 2019/03/18. PubMed PMID: 30889795; PubMed Central PMCID: PMCPMC6471355.

48. Nemeth, K., Leelahavanichkul, A., Yuen, P. S., Mayer, B., Parmelee, A., Doi, K., et al. (2009). Bone marrow stromal cells attenuate sepsis via prostaglandin E(2)-dependent reprogramming of host macrophages to increase their interleukin-10 production. Nature Medicine, 15(1), 42-49. https://doi.org/10.1038/nm.1905 PubMed PMID: 19098906; PubMed Central PMCID: PMC2706487.

49. Mei, S. H., McCarter, S. D., Deng, Y., Parker, C. H., Liles, W. C., \& Stewart, D. J. (2007). Prevention of LPS-induced acute lung injury in mice by mesenchymal stem cells overexpressing angiopoietin 1. PLoS Medicine, 4(9), e269. https://doi.org/10. 1371/journal.pmed.0040269 PubMed PMID: 17803352; PubMed Central PMCID: PMC1961632.

50. Krasnodembskaya, A., Samarani, G., Song, Y., Zhuo, H., Su, X., Lee, J. W., Gupta, N., Petrini, M., \& Matthay, M. A. (2012). Human mesenchymal stem cells reduce mortality and bacteremia in gram-negative sepsis in mice in part by enhancing the phagocytic activity of blood monocytes. American Journal of Physiology. Lung Cellular and Molecular Physiology, 302(10), L1003-L1013. https://doi.org/10.1152/ajplung.00180.2011 PubMed PMID: 22427530; PubMed Central PMCID: PMC3362255.

51. Park, J. S., Suryaprakash, S., Lao, Y. H., \& Leong, K. W. (2015). Engineering mesenchymal stem cells for regenerative medicine and drug delivery. Methods, 84, 3-16. https://doi.org/10.1016/j. 
ymeth.2015.03.002 Epub 2015/03/11. PubMed PMID: 25770356; PubMed Central PMCID: PMCPMC4526354.

52. Collino, F., Bruno, S., Deregibus, M. C., Tetta, C., \& Camussi, G. (2011). MicroRNAs and mesenchymal stem cells. Vitamins and Hormones, 87, 291-320. https://doi.org/10.1016/B978-0-12386015-6.00033-0.

53. Keating, A. (2012). Mesenchymal stromal cells: New directions. Cell Stem Cell, 10(6), 709-716. https://doi.org/10.1016/j.stem. 2012.05.015.

54. dos Santos, C. C., Murthy, S., Hu, P., Shan, Y., Haitsma, J. J., Mei, S. H., et al. (2012). Network analysis of transcriptional responses induced by mesenchymal stem cell treatment of experimental sepsis. The American Journal of Pathology, 181(5), 1681-1692. https://doi.org/10.1016/j.ajpath.2012.08.009.

55. Savukinas, U. B., Enes, S. R., Sjöland, A. A., \& WestergrenThorsson, G. (2016). Concise review: The bystander effect: Mesenchymal stem cell-mediated lung repair. Stem Cells, 34(6), 1437-1444. Epub 2016/03/29. https://doi.org/10.1002/stem.2357.

56. Nauta, A. J., \& Fibbe, W. E. (2007). Immunomodulatory properties of mesenchymal stromal cells. Blood, 110(10), 3499-3506. Epub 2007/07/30. https://doi.org/10.1182/blood-2007-02069716.

57. Beyth, S., Borovsky, Z., Mevorach, D., Liebergall, M., Gazit, Z., Aslan, H., Galun, E., \& Rachmilewitz, J. (2005). Human mesenchymal stem cells alter antigen-presenting cell maturation and induce T-cell unresponsiveness. Blood, 105(5), 2214-2219. Epub 2004/10/28. https://doi.org/10.1182/blood-2004-07-2921.

58. Corcione, A., Benvenuto, F., Ferretti, E., Giunti, D., Cappiello, V., Cazzanti, F., Risso, M., Gualandi, F., Mancardi, G. L., Pistoia, V., \& Uccelli, A. (2006). Human mesenchymal stem cells modulate B-cell functions. Blood, 107(1), 367-372. Epub 2005/09/01. https://doi.org/10.1182/blood-2005-07-2657.

59. Rafei, M., Hsieh, J., Fortier, S., Li, M., Yuan, S., Birman, E., Forner, K., Boivin, M. N., Doody, K., Tremblay, M., Annabi, B., \& Galipeau, J. (2008). Mesenchymal stromal cell-derived CCL2 suppresses plasma cell immunoglobulin production via STAT3 inactivation and PAX5 induction. Blood, 112(13), 4991-4998. Epub 2008/09/23. https://doi.org/10.1182/blood2008-07-166892.

60. Comoli, P., Ginevri, F., Maccario, R., Avanzini, M. A., Marconi, M., Groff, A., Cometa, A., Cioni, M., Porretti, L., Barberi, W., Frassoni, F., \& Locatelli, F. (2008). Human mesenchymal stem cells inhibit antibody production induced in vitro by allostimulation. Nephrology, Dialysis, Transplantation, 23(4), 1196-1202. Epub 2007/11/19. https://doi.org/10.1093/ndt/ gfm740.

61. Amatullah, H., Shan, Y., Beauchamp, B. L., Gali, P. L., Gupta, S., Maron-Gutierrez, T., Speck, E. R., Fox-Robichaud, A. E., Tsang, J. L., Mei, S. H., Mak, T. W., Rocco, P. R., Semple, J. W., Zhang, H., Hu, P., Marshall, J. C., Stewart, D. J., Harper, M. E., Liaw, P. C., Liles, W. C., Dos Santos, C. C., \& Canadian Critical Care Translational Biology Group. (2017). DJ-1/PARK7 impairs bacterial clearance in sepsis. American Journal of Respiratory and Critical Care Medicine, 195(7), 889-905. https://doi.org/10. 1164/rccm.201604-0730OC.

62. Abreu, S. C., Enes, S. R., Dearborn, J., Goodwin, M., Coffey, A., Borg, Z. D., et al. (2019. Epub 2019/09/25). Lung inflammatory environments differentially alter mesenchymal stromal cell behavior. The American Journal of Physiology-Lung Cellular and Molecular Physiology. https://doi.org/10.1152/ajplung.00263. 2019.

63. Bernardo, M. E., \& Fibbe, W. E. (2013). Mesenchymal stromal cells: Sensors and switchers of inflammation. Cell Stem Cell, 13(4), 392-402. https://doi.org/10.1016/j.stem.2013.09.006.

64. Waterman, R. S., Tomchuck, S. L., Henkle, S. L., \& Betancourt, A. M. (2010). A new mesenchymal stem cell (MSC) paradigm:
Polarization into a pro-inflammatory MSC1 or an immunosuppressive MSC2 phenotype. PLoS One, 5(4), e10088. https://doi. org/10.1371/journal.pone.0010088 Epub 2010/04/26. PubMed PMID: 20436665; PubMed Central PMCID: PMCPMC2859930.

65. Godwin, J. W., Pinto, A. R., \& Rosenthal, N. A. (2013). Macrophages are required for adult salamander limb regeneration. Proceedings of the National Academy of Sciences of the United States of America, 110(23), 9415-9420. https://doi.org/10.1073/ pnas.1300290110 Epub 2013/05/20. PubMed PMID: 23690624; PubMed Central PMCID: PMCPMC3677454.

66. El Kebir, D., József, L., Pan, W., Wang, L., Petasis, N. A., Serhan, C. N., et al. (2009). 15-epi-lipoxin A4 inhibits myeloperoxidase signaling and enhances resolution of acute lung injury. The American Journal of Respiratory and Critical Care Medicine, 180(4), 311-319. https://doi.org/10.1164/rccm.200810-16010C Epub 2009/05/29. PubMed PMID: 19483113; PubMed Central PMCID: PMCPMC2731808.

67. Hodgkinson, C. P., Gomez, J. A., Mirotsou, M., \& Dzau, V. J. (2010). Genetic engineering of mesenchymal stem cells and its application in human disease therapy. Human Gene Therapy, 21(11), 1513-1526. https://doi.org/10.1089/hum.2010.165 Epub 2010/10/22. PubMed PMID: 20825283; PubMed Central PMCID: PMCPMC2978545.

68. Nowakowski, A., Walczak, P., Lukomska, B., \& Janowski, M. (2016). Genetic engineering of mesenchymal stem cells to induce their migration and survival. Stem Cells International, 2016, 4956063. https://doi.org/10.1155/2016/4956063 Epub 2016/05/ 03. PubMed PMID: 27242906; PubMed Central PMCID: PMCPMC4868914.

69. Greco, S. J., \& Rameshwar, P. (2012). Mesenchymal stem cells in drug/gene delivery: Implications for cell therapy. Therapeutic Delivery, 3(8), 997-1004.

70. Oggu, G. S., Sasikumar, S., Reddy, N., Ella, K. K. R., Rao, C. M., \& Bokara, K. K. (2017). Gene delivery approaches for mesenchymal stem cell therapy: Strategies to increase efficiency and specificity. Stem Cell Reviews, 13(6), 725-740. https://doi.org/10. 1007/s12015-017-9760-2.

71. Byrne, S. M., Mali, P., \& Church, G. M. (2014). Genome editing in human stem cells. Methods in Enzymology, 546, 119-138. https://doi.org/10.1016/B978-0-12-801185-0.00006-4 PubMed PMID: 25398338; PubMed Central PMCID: PMCPMC4408990.

72. Zhang, J. H., Adikaram, P., Pandey, M., Genis, A., \& Simonds, W. F. (2016). Optimization of genome editing through CRISPRCas9 engineering. Bioengineered, 7(3), 166-174. https://doi.org/ 10.1080/21655979.2016.1189039 PubMed PMID: 27340770; PubMed Central PMCID: PMCPMC4927198.

73. Gerace, D., Martiniello-Wilks, R., Nassif, N. T., Lal, S., Steptoe, R., \& Simpson, A. M. (2017). CRISPR-targeted genome editing of mesenchymal stem cell-derived therapies for type 1 diabetes: a path to clinical success? Stem Cell Research \& Therapy, 8(1), 62. https://doi.org/10.1186/s13287-017-0511-8 Epub 2017/03/09. PubMed PMID: 28279194; PubMed Central PMCID: PMCPMC5345178.

74. Vanoli, F., Tomishima, M., Feng, W., Lamribet, K., Babin, L., Brunet, E., et al. (2017). CRISPR-Cas9-guided oncogenic chromosomal translocations with conditional fusion protein expression in human mesenchymal cells. Proceedings of the National Academy of Sciences of the United States of America, 114(14), 3696-3701. https://doi.org/10.1073/pnas.1700622114 Epub 2017/03/21. PubMed PMID: 28325870; PubMed Central PMCID: PMCPMC5389291.

75. Bak, R. O., Dever, D. P., \& Porteus, M. H. (2018). CRISPR/Cas9 genome editing in human hematopoietic stem cells. Nature Protocols, 13(2), 358-376. https://doi.org/10.1038/nprot.2017. 143 Epub 2018/01/25. PubMed PMID: 29370156; PubMed Central PMCID: PMCPMC5826598. 
76. Lundstrom, K. (2018). Viral vectors in gene therapy. Diseases, 6(2), 42. https://doi.org/10.3390/diseases6020042 PubMed Central PMCID: PMCPMC6023384.

77. Kotterman, M. A., Chalberg, T. W., \& Schaffer, D. V. (2015). Viral vectors for gene therapy: Translational and clinical outlook. Annual Review of Biomedical Engineering, 17, 63-89. https://doi. org/10.1146/annurev-bioeng-071813-104938.

78. David, R. M., \& Doherty, A. T. (2017). Viral vectors: The road to reducing genotoxicity. Toxicological Sciences, 155(2), 315-325. Epub 2016/11/01. https://doi.org/10.1093/toxsci/kfw220.

79. Meyerrose, T. E., Roberts, M., Ohlemiller, K. K., Vogler, C. A., Wirthlin, L., Nolta, J. A., et al. (2008). Lentiviral-transduced human mesenchymal stem cells persistently express therapeutic levels of enzyme in a xenotransplantation model of human disease. Stem Cells, 26(7), 1713-1722. https://doi.org/10.1634/ stemcells.2008-0008 Epub 2008/04/24. PubMed PMID: 18436861; PubMed Central PMCID: PMCPMC2736639.

80. Milone, M. C. \& O'Doherty, U. (2018). Clinical use of lentiviral vectors. Leukemia, 32(7), 1529-1541. https://doi.org/10.1038/ s41375-018-0106-0.

81. Escors, D., \& Breckpot, K. (2010). Lentiviral vectors in gene therapy: Their current status and future potential. Archivum Immunologiae et Therapiae Experimentalis (Warsz), 58(2), 107119. https://doi.org/10.1007/s00005-010-0063-4 Epub 2010/02/ 09. PubMed PMID: 20143172; PubMed Central PMCID: PMCPMC2837622.

82. Naso, M. F., Tomkowicz, B., Perry, W. L., \& Strohl, W. R. (2017). Adeno-associated virus (AAV) as a vector for gene therapy. BioDrugs, 31(4), 317-334. https://doi.org/10.1007/s40259017-0234-5 PubMed PMID: 28669112; PubMed Central PMCID: PMCPMC5548848.

83. Wu, Z., Asokan, A., \& Samulski, R. J. (2006). Adeno-associated virus serotypes: Vector toolkit for human gene therapy. Molecular Therapy, 14(3), 316-327. Epub 2006/07/07. https://doi.org/10. 1016/j.ymthe.2006.05.009.

84. Hirsch, M. L., Wolf, S. J., \& Samulski, R. J. (2016). Delivering transgenic DNA exceeding the carrying capacity of AAV vectors. Methods in Molecular Biology, 1382, 21-39. https://doi.org/10. 1007/978-1-4939-3271-9 2 PubMed PMID: 26611576; PubMed Central PMCID: PMCPMC4971574.

85. Stender, S., Murphy, M., O'Brien, T., Stengaard, C., UlrichVinther, M., Søballe, K., et al. (2007). Adeno-associated viral vector transduction of human mesenchymal stem cells. European Cells \& Materials, 13, 93-99 discussion 9. Epub 2007/05/31.

86. Gabriel, N., Samuel, R., \& Jayandharan, G. R. (2017). Targeted delivery of AAV-transduced mesenchymal stromal cells to hepatic tissue for ex vivo gene therapy. Journal of Tissue Engineering and Regenerative Medicine, 11(5), 1354-1364. Epub 2015/06/05. https://doi.org/10.1002/term.2034.

87. Wold, W. S., \& Toth, K. (2013). Adenovirus vectors for gene therapy, vaccination and cancer gene therapy. Current Gene Therapy, 13(6), 421-433. https://doi.org/10.2174/ 1566523213666131125095046 PubMed PMID: 24279313; PubMed Central PMCID: PMCPMC4507798.

88. Lee, C. S., Bishop, E. S., Zhang, R., Yu, X., Farina, E. M., Yan, S., et al. (2017). Adenovirus-mediated gene delivery: Potential applications for gene and cell-based therapies in the New Era of personalized medicine. Genes \& Diseases, 4(2), 43-63. https://doi. org/10.1016/j.gendis.2017.04.001 Epub 2017/04/27. PubMed PMID: 28944281; PubMed Central PMCID: PMCPMC5609467.

89. Yin, H., Kanasty, R. L., Eltoukhy, A. A., Vegas, A. J., Dorkin, J. R., \& Anderson, D. G. (2014). Non-viral vectors for gene-based therapy. Nature Reviews Genetics, 15(8), 541-555. Epub 2014/07/15. https://doi.org/10.1038/nrg3763.
90. Hardee, C. L., Arévalo-Soliz, L. M., Hornstein, B. D., \& Zechiedrich, L. (2017). Advances in non-viral DNA vectors for gene therapy. Genes (Basel), 8(2). https://doi.org/10.3390/ genes8020065 Epub 2017/02/10. PubMed PMID: 28208635; PubMed Central PMCID: PMCPMC5333054.

91. Suschak, J. J., Williams, J. A., \& Schmaljohn, C. S. (2017). Advancements in DNA vaccine vectors, non-mechanical delivery methods, and molecular adjuvants to increase immunogenicity. Human Vaccines \& Immunotherapeutics, 13(12), 2837-2848. https://doi.org/10.1080/21645515.2017.1330236 Epub 2017/06/ 12. PubMed PMID: 28604157; PubMed Central PMCID: PMCPMC5718814.

92. Ramamoorth, M., \& Narvekar, A. (2015). Non viral vectors in gene therapy- an overview. Journal of Clinical and Diagnostic Research, 9(1), GE01-GE06. https://doi.org/10.7860/JCDR/ 2015/10443.5394 Epub 2015/01/01. PubMed PMID: 25738007; PubMed Central PMCID: PMCPMC4347098.

93. Boura, J. S., Santos, F. D., Gimble, J. M., Cardoso, C. M., Madeira, C., Cabral, J. M., et al. (2013). Direct head-to-head comparison of cationic liposome-mediated gene delivery to mesenchymal stem/stromal cells of different human sources: a comprehensive study. Human Gene Therapy Methods, 24(1), 38-48. https://doi.org/10.1089/hgtb.2012.185 PubMed PMID: 23360350; PubMed Central PMCID: PMCPMC4015075.

94. Li, L. M., Ruan, G. X., HuangFu, M. Y., Chen, Z. L., Liu, H. N., Li, L. X., et al. (2015). ScreenFect A: An efficient and low toxic liposome for gene delivery to mesenchymal stem cells. International Journal of Pharmaceutics, 488(1-2), 1-11. Epub 2015/04/17. https://doi.org/10.1016/j.ijpharm.2015.04.050.

95. Das, J., Choi, Y. J., Yasuda, H., Han, J. W., Park, C., Song, H., et al. (2016). Efficient delivery of C/EBP beta gene into human mesenchymal stem cells via polyethylenimine-coated gold nanoparticles enhances adipogenic differentiation. Scientific Reports, 6, 33784. https://doi.org/10.1038/srep33784 Epub 2016/09/28. PubMed PMID: 27677463; PubMed Central PMCID: PMCPMC5039411.

96. Chen, Z. Y., He, C. Y., Ehrhardt, A., \& Kay, M. A. (2003). Minicircle DNA vectors devoid of bacterial DNA result in persistent and high-level transgene expression in vivo. Molecular Therapy, 8(3), 495-500.

97. Huang, M., Chen, Z., Hu, S., Jia, F., Li, Z., Hoyt, G., et al. (2009). Novel minicircle vector for gene therapy in murine myocardial infarction. Circulation, 120(11 Suppl), S230-S237. https://doi. org/10.1161/CIRCULATIONAHA.108.841155 PubMed PMID: 19752373; PubMed Central PMCID: PMCPMC3163107.

98. Munye, M. M., Tagalakis, A. D., Barnes, J. L., Brown, R. E., McAnulty, R. J., Howe, S. J., et al. (2016). Minicircle DNA provides enhanced and prolonged transgene expression following airway gene transfer. Scientific Reports, 6, 23125. https://doi. org/10.1038/srep23125 Epub 2016/03/15. PubMed PMID: 26975732; PubMed Central PMCID: PMCPMC4792149.

99. Boura, J. S., Vance, M., Y in, W., Madeira, C., Lobato da Silva, C., Porada, C. D., et al. (2014). Evaluation of gene delivery strategies to efficiently overexpress functional HLA-G on human bone marrow stromal cells. Molecular Therapy: Methods \& Clinical Development, 2014(1). https://doi.org/10.1038/mtm.2014.41 PubMed PMID: 25279386; PubMed Central PMCID: PMCPMC4178537.

100. Tidd, N., Michelsen, J., Hilbert, B., \& Quinn, J. C. (2017). Minicircle Mediated Gene Delivery to Canine and Equine Mesenchymal Stem Cells. The International Journal of Molecular Sciences, 18(4). https://doi.org/10.3390/ ijms18040819 Epub 2017/04/12. PubMed PMID: 28417917; PubMed Central PMCID: PMCPMC5412403.

101. Xu, J., Qu, J., Cao, L., Sai, Y., Chen, C., He, L., \& Yu, L. (2008). Mesenchymal stem cell-based angiopoietin-1 gene therapy for 
acute lung injury induced by lipopolysaccharide in mice. The Journal of Pathology, 214(4), 472-481. https://doi.org/10.1002/ path.2302.

102. Zhao, Y. F., Luo, Y. M., Xiong, W., Ding, W., Li, Y. R., Zhao, W., Zeng, H. Z., Gao, H. C., \& Wu, X. L. (2015). Mesenchymal stem cell-based FGF2 gene therapy for acute lung injury induced by lipopolysaccharide in mice. European Review for Medical and Pharmacological Sciences, 19(5), 857-865.

103. Chen, J., Li, C., Gao, X., Liang, Z., Yu, L., Li, Y., et al. (2013). Keratinocyte growth factor gene delivery via mesenchymal stem cells protects against lipopolysaccharide-induced acute lung injury in mice. PLoS One, 8(12), e83303. https://doi.org/10.1371/ journal.pone.0083303 Epub 2013/12/18. PubMed PMID: 24367590; PubMed Central PMCID: PMCPMC3867420.

104. Pati, S., Croze, R., Gibb, S., Potter, D., Fang, X., \& Matthay, M. A. (2017). Conditioned media from keratinocyte growth factor modified mesenchymal stromal cells reduces pulmonary vascular permeability. The FASEB Journal, (31), 1073.9-1073.9. https:// doi.org/10.1096/fasebj.31.1_supplement.1073.9.

105. Li, Y., Zeng, Z., Cao, Y., Liu, Y., Ping, F., Liang, M., et al. (2016a). Angiotensin-converting enzyme 2 prevents lipopolysaccharide-induced rat acute lung injury via suppressing the ERK1/2 and NF-kB signaling pathways. Scientific Reports, 6 , 27911. https://doi.org/10.1038/srep27911 Epub 2016/06/15. PubMed PMID: 27302421; PubMed Central PMCID: PMCPMC4908402.

106. Imai, Y., Kuba, K., Rao, S., Huan, Y., Guo, F., Guan, B., Yang, P., Sarao, R., Wada, T., Leong-Poi, H., Crackower, M. A., Fukamizu, A., Hui, C. C., Hein, L., Uhlig, S., Slutsky, A. S., Jiang, C., \& Penninger, J. M. (2005). Angiotensin-converting enzyme 2 protects from severe acute lung failure. Nature, 436(7047), 112-116. https://doi.org/10.1038/nature03712.

107. Min, F., Gao, F., Li, Q., \& Liu, Z. (2015). Therapeutic effect of human umbilical cord mesenchymal stem cells modified by angiotensin-converting enzyme 2 gene on bleomycin-induced lung fibrosis injury. Molecular Medicine Reports, 11(4), 23872396. https://doi.org/10.3892/mmr.2014.3025 Epub 2014/12/01. PubMed PMID: 25435005; PubMed Central PMCID: PMCPMC4337478.

108. He, H., Liu, L., Chen, Q., Liu, A., Cai, S., Yang, Y., Lu, X., \& Qiu, H. (2015). Mesenchymal stem cells overexpressing angiotensin-converting enzyme 2 rescue lipopolysaccharideinduced lung injury. Cell Transplantation, 24(9), 1699-1715. Epub 2014/10/06. https://doi.org/10.3727/096368914X685087.

109. Khoury, M., Cuenca, J., Cruz, F. F., Figueroa, F. E., Rocco, P. R. M., \& Weiss, D. J. (2020). Current status of cell-based therapies for respiratory virus infections: applicability to COVID-19. The European Respiratory Journal, 55(6). https://doi.org/10.1183/ 13993003.00858-2020 Epub 2020/06/04. PubMed PMID: 32265310; PubMed Central PMCID: PMCPMC7144273.

110. Qu, W., Wang, Z., Hare, J. M., Bu, G., Mallea, J. M., Pascual, J. M., Caplan, A. I., Kurtzberg, J., Zubair, A. C., Kubrova, E., Engelberg-Cook, E., Nayfeh, T., Shah, V. P., Hill, J. C., Wolf, M. E., Prokop, L. J., Murad, M. H., \& Sanfilippo, F. P. (2020. Epub 2020/05/29). Cell-based therapy to reduce mortality from COVID-19: Systematic review and meta-analysis of human studies on acute respiratory distress syndrome. Stem Cells Translational Medicine. https://doi.org/10.1002/sctm.20-0146.

111. Qin, H., \& Zhao, A. (2020). Mesenchymal stem cell therapy for acute respiratory distress syndrome: From basic to clinics. Protein \& Cell. https://doi.org/10.1007/s13238-020-00738-2 Epub 2020/06/09. PubMed PMID: 32519302; PubMed Central PMCID: PMCPMC7282699.

112. Leng, Z., Zhu, R., Hou, W., Feng, Y., Yang, Y., Han, Q., et al. (2020). Transplantation of ACE2. Aging and Disease, 11(2), 216228. https://doi.org/10.14336/AD.2020.0228 Epub 2020/03/09.
PubMed PMID: 32257537; PubMed Central PMCID: PMCPMC7069465.

113. Yagami, A., Orihara, K., Morita, H., Futamura, K., Hashimoto, N., Matsumoto, K., Saito, H., \& Matsuda, A. (2010). IL-33 mediates inflammatory responses in human lung tissue cells. Journal of Immunology, 185(10), 5743-5750. Epub 2010/10/06. https://doi. org/10.4049/jimmunol.0903818.

114. Martínez-González, I., Roca, O., Masclans, J. R., Moreno, R., Salcedo, M. T., Baekelandt, V., Cruz, M. J., Rello, J., \& Aran, J. M. (2013). Human mesenchymal stem cells overexpressing the IL-33 antagonist soluble IL-1 receptor-like-1 attenuate endotoxin-induced acute lung injury. American Journal of Respiratory Cell and Molecular Biology, 49(4), 552-562. https://doi.org/10.1165/rcmb.2012-0406OC.

115. Manning, E., Pham, S., Li, S., Vazquez-Padron, R. I., Mathew, J., Ruiz, P., \& Salgar, S. K. (2010). Interleukin-10 delivery via mesenchymal stem cells: A novel gene therapy approach to prevent lung ischemia-reperfusion injury. Human Gene Therapy, 21(6), 713-727. https://doi.org/10.1089/hum.2009.147.

116. Wang, Y., Li, Y., Song, L., Jiang, S., \& Zhang, S. (2016b). The transplantation of Akt-overexpressing amniotic fluid-derived mesenchymal stem cells protects the heart against ischemiareperfusion injury in rabbits. Molecular Medicine Reports, 14(1), 234-242. https://doi.org/10.3892/mmr.2016.5212 Epub 2016/05/ 05. PubMed PMID: 27151366; PubMed Central PMCID: PMCPMC4918560.

117. Ishii, M., Numaguchi, Y., Okumura, K., Kubota, R., Ma, X., Murakami, R., Naruse, K., \& Murohara, T. (2009). Mesenchymal stem cell-based gene therapy with prostacyclin synthase enhanced neovascularization in hindlimb ischemia. Atherosclerosis, 206(1), 109-118. Epub 2009/03/11. https://doi. org/10.1016/j.atherosclerosis.2009.02.023.

118. Xiang, Q., Hong, D., Liao, Y., Cao, Y., Liu, M., Pang, J., Zhou, J., Wang, G., Yang, R., Wang, M., \& Xiang, A. P. (2017). Overexpression of Gremlin 1 in mesenchymal stem cells improves hindlimb ischemia in mice by enhancing cell survival. Journal of Cellular Physiology, 232(5), 996-1007. Epub 2016/12/20. https:// doi.org/10.1002/jcp.25578.

119. Yu, X., Chen, D., Zhang, Y., Wu, X., Huang, Z., Zhou, H., Zhang, Y., \& Zhang, Z. (2012). Overexpression of CXCR4 in mesenchymal stem cells promotes migration, neuroprotection and angiogenesis in a rat model of stroke. Journal of the Neurological Sciences, 316(1-2), 141-149. Epub 2012/01/26. https://doi.org/10.1016/j. jns.2012.01.001.

120. Onda, T., Honmou, O., Harada, K., Houkin, K., Hamada, H., \& Kocsis, J. D. (2008). Therapeutic benefits by human mesenchymal stem cells (hMSCs) and Ang-1 gene-modified hMSCs after cerebral ischemia. The Journal of Cerebral Blood Flow \& Metabolism, 28(2), 329-340. https://doi.org/10.1038/sj.jcbfm. 9600527 Epub 2007/07/18. PubMed PMID: 17637706; PubMed Central PMCID: PMCPMC2605394.

121. Toyama, K., Honmou, O., Harada, K., Suzuki, J., Houkin, K., Hamada, H., \& Kocsis, J. D. (2009). Therapeutic benefits of angiogenetic gene-modified human mesenchymal stem cells after cerebral ischemia. Experimental Neurology, 216(1), 47-55. Epub 2008/11/27. https://doi.org/10.1016/j.expneurol.2008.11.010.

122. Mangi, A. A., Noiseux, N., Kong, D., He, H., Rezvani, M., Ingwall, J. S., \& Dzau, V. J. (2003). Mesenchymal stem cells modified with Akt prevent remodeling and restore performance of infarcted hearts. Nature Medicine, 9(9), 1195-1201. Epub 2003/08/10. https://doi.org/10.1038/nm912.

123. Noiseux, N., Gnecchi, M., Lopez-Ilasaca, M., Zhang, L., Solomon, S. D., Deb, A., Dzau, V. J., \& Pratt, R. E. (2006). Mesenchymal stem cells overexpressing Akt dramatically repair infarcted myocardium and improve cardiac function despite infrequent cellular fusion or differentiation. Molecular Therapy, 14(6), 
840-850. Epub 2006/09/11. https://doi.org/10.1016/j.ymthe. 2006.05.016

124. Shujia, J., Haider, H. K., Idris, N. M., Lu, G., \& Ashraf, M. (2008). Stable therapeutic effects of mesenchymal stem cell-based multiple gene delivery for cardiac repair. Cardiovascular Research, 77(3), 525-533. Epub 2007/11/21. https://doi.org/10.1093/cvr/ cvm077.

125. Li, W., Ma, N., Ong, L. L., Nesselmann, C., Klopsch, C., Ladilov, Y., Furlani, D., Piechaczek, C., Moebius, J. M., Lützow, K., Lendlein, A., Stamm, C., Li, R. K., \& Steinhoff, G. (2007). Bcl2 engineered MSCs inhibited apoptosis and improved heart function. Stem Cells, 25(8), 2118-2127. Epub 2007/05/03. https://doi. org/10.1634/stemcells.2006-0771.

126. Grunewald, M., Avraham, I., Dor, Y., Bachar-Lustig, E., Itin, A., Jung, S., et al. (2006). VEGF-induced adult neovascularization: Recruitment, retention, and role of accessory cells. Cell, 124(1), 175-189. https://doi.org/10.1016/j.cell.2005.10.036.

127. Tang, J., Wang, J., Yang, J., Kong, X., Zheng, F., Guo, L., Zhang, L., \& Huang, Y. (2009). Mesenchymal stem cells over-expressing SDF-1 promote angiogenesis and improve heart function in experimental myocardial infarction in rats. European Journal of Cardio-Thoracic Surgery, 36(4), 644-650. Epub 2009/06/12. https://doi.org/10.1016/j.ejcts.2009.04.052.

128. Tang, J., Wang, J., Zheng, F., Kong, X., Guo, L., Yang, J., Zhang, L., \& Huang, Y. (2010). Combination of chemokine and angiogenic factor genes and mesenchymal stem cells could enhance angiogenesis and improve cardiac function after acute myocardial infarction in rats. Molecular and Cellular Biochemistry, 339(1-2), 107-118. Epub 2010/01/08. https://doi.org/10.1007/s11010-0090374-0.

129. Bao, C., Guo, J., Lin, G., Hu, M., \& Hu, Z. (2008). TNFR genemodified mesenchymal stem cells attenuate inflammation and cardiac dysfunction following MI. Scandinavian Cardiovascular Journal, 42(1), 56-62. https://doi.org/10.1080/ 14017430701543556.

130. Hnatiuk, A. P., Ong, S. G., Olea, F. D., Locatelli, P., Riegler, J., Lee, W. H., et al. (2016). Allogeneic mesenchymal stromal cells overexpressing mutant human hypoxia-inducible factor 1- $\alpha$ $($ HIF $1-\alpha)$ in an ovine model of acute myocardial infarction. Journal of the American Heart Association, 5(7). https://doi.org/ 10.1161/JAHA.116.003714 Epub 2016/07/06. PubMed PMID: 27385426; PubMed Central PMCID: PMCPMC5015403.

131. Gómez-Mauricio, G., Moscoso, I., Martín-Cancho, M. F., Crisóstomo, V., Prat-Vidal, C., Báez-Díaz, C., et al. (2016). Combined administration of mesenchymal stem cells overexpressing IGF-1 and HGF enhances neovascularization but moderately improves cardiac regeneration in a porcine model. Stem Cell Research \& Therapy, 7(1), 94. https://doi.org/10.1186/ s13287-016-0350-z Epub 2016/07/16. PubMed PMID: 27423905; PubMed Central PMCID: PMCPMC4947339.

132. Wen, Z., Huang, W., Feng, Y., Cai, W., Wang, Y., Wang, X., et al. (2014). MicroRNA-377 regulates mesenchymal stem cell-induced angiogenesis in ischemic hearts by targeting VEGF. PLoS One, 9(9), e104666. https://doi.org/10.1371/journal.pone.0104666 Epub 2014/09/24. PubMed PMID: 25251394; PubMed Central PMCID: PMCPMC4174502.

133. Zhang, J. B., Wang, X. Q., Lu, G. L., Huang, H. S., \& Xu, S. Y. (2017). Adipose-derived mesenchymal stem cells therapy for acute kidney injury induced by ischemia-reperfusion in a rat model. Clinical and Experimental Pharmacology \& Physiology, 44(12), 1232-1240. Epub 2017/10/12. https://doi.org/10.1111/ 1440-1681.12811.

134. Peired, A. J., Sisti, A., \& Romagnani, P. (2016). Mesenchymal stem cell-based therapy for kidney disease: A review of clinical evidence. Stem Cells International, 2016, 4798639. https://doi. org/10.1155/2016/4798639 Epub 2016/09/19. PubMed PMID: 27721835; PubMed Central PMCID: PMCPMC5046016.

135. Roudkenar, M. H., Halabian, R., Tehrani, H. A., Amiri, F., Jahanian-Najafabadi, A., Roushandeh, A. M., et al. (2018). Lipocalin 2 enhances mesenchymal stem cell-based cell therapy in acute kidney injury rat model. Cytotechnology, 70(1), 103-117. https://doi.org/10.1007/s10616-017-0107-2 Epub 2017/06/02. PubMed PMID: 28573544; PubMed Central PMCID: PMCPMC5809639.

136. Kanda, J., Mori, K., Kawabata, H., Kuwabara, T., Mori, K. P., Imamaki, H., Kasahara, M., Yokoi, H., Mizumoto, C., Thoennissen, N. H., Koeffler, H. P., Barasch, J., Takaori-Kondo, A., Mukoyama, M., \& Nakao, K. (2015). An AKI biomarker lipocalin 2 in the blood derives from the kidney in renal injury but from neutrophils in normal and infected conditions. Clinical and Experimental Nephrology, 19(1), 99-106. Epub 2014/03/06. https://doi.org/10.1007/s10157-014-0952-7.

137. Mohammadzadeh-Vardin, M., Habibi Roudkenar, M., \& Jahanian-Najafabadi, A. (2015). Adenovirus-mediated over-expression of Nrf2 within mesenchymal stem cells (MSCs) protected rats against acute kidney injury. Advanced Pharmaceutical Bulletin, 5(2), 201-208. https://doi.org/10. 15171/apb.2015.028 Epub 2015/06/01. PubMed PMID: 26236658; PubMed Central PMCID: PMCPMC4517083.

138. Volarevic, V., Nurkovic, J., Arsenijevic, N., \& Stojkovic, M. (2014). Concise review: Therapeutic potential of mesenchymal stem cells for the treatment of acute liver failure and cirrhosis. Stem Cells, 32(11), 2818-2823. https://doi.org/10.1002/stem. 1818.

139. Aurich, I., Mueller, L. P., Aurich, H., Luetzkendorf, J., Tisljar, K., Dollinger, M. M., et al. (2007). Functional integration of hepatocytes derived from human mesenchymal stem cells into mouse livers. Gut, 56(3), 405-415. https://doi.org/10.1136/gut.2005. 090050 Epub 2006/08/23. PubMed PMID: 16928726; PubMed Central PMCID: PMCPMC1856821.

140. Lee, K. D., Kuo, T. K., Whang-Peng, J., Chung, Y. F., Lin, C. T., Chou, S. H., et al. (2004). In vitro hepatic differentiation of human mesenchymal stem cells. Hepatology, 40(6), 1275-1284. https:// doi.org/10.1002/hep.20469.

141. Banas, A., Teratani, T., Yamamoto, Y., Tokuhara, M., Takeshita, F., Quinn, G., Okochi, H., \& Ochiya, T. (2007). Adipose tissuederived mesenchymal stem cells as a source of human hepatocytes. Hepatology, 46(1), 219-228. https://doi.org/10.1002/hep. 21704.

142. Zagoura, D. S., Roubelakis, M. G., Bitsika, V., Trohatou, O., Pappa, K. I., Kapelouzou, A., Antsaklis, A., \& Anagnou, N. P. (2012). Therapeutic potential of a distinct population of human amniotic fluid mesenchymal stem cells and their secreted molecules in mice with acute hepatic failure. Gut, 61(6), 894-906. Epub 2011/10/13. https://doi.org/10.1136/gutjnl-2011-300908.

143. Ma, H. C., Shi, X. L., Ren, H. Z., Yuan, X. W., \& Ding, Y. T. (2014). Targeted migration of mesenchymal stem cells modified with CXCR4 to acute failing liver improves liver regeneration. World Journal of Gastroenterology, 20(40), 14884-14894. https://doi.org/10.3748/wjg.v20.i40.14884 PubMed PMID: 25356048; PubMed Central PMCID: PMCPMC4209551.

144. Wang, K., Li, Y., Zhu, T., Zhang, Y., Li, W., Lin, W., et al. (2017). Overexpression of c-Met in bone marrow mesenchymal stem cells improves their effectiveness in homing and repair of acute liver failure. Stem Cell Research \& Therapy, 8(1), 162. https://doi.org/ 10.1186/s13287-017-0614-2. Epub 2017/07/05. PubMed PMID: 28679425; PubMed Central PMCID: PMCPMC5499016.

145. Zhu, C., Li, Y., Li, W., Wu, Q., \& Gao, R. (2012). Gene transfer of c-met confers protection against D-galactosamine/lipopolysaccharide-induced acute liver failure. Digestive Diseases and Sciences, 
57(4), 925-934. Epub 2012/01/24. https://doi.org/10.1007/ s10620-012-2052-4.

146. Soland, M. A., Bego, M. G., Colletti, E., Porada, C. D., Zanjani, E. D., St Jeor, S., et al. (2012). Modulation of human mesenchymal stem cell immunogenicity through forced expression of human cytomegalovirus us proteins. PLoS One, 7(5), e36163. https:// doi.org/10.1371/journal.pone.0036163 Epub 2012/05/30. PubMed PMID: 22666319; PubMed Central PMCID: PMCPMC3364258.

147. Lee, S., Choi, E., Cha, M. J., \& Hwang, K. C. (2015). Cell adhesion and long-term survival of transplanted mesenchymal stem cells: a prerequisite for cell therapy. Oxidative Medicine and Cellular Longevity, 2015, 632902. https://doi.org/10.1155/2015/ 632902 Epub 2015/02/02. PubMed PMID: 25722795; PubMed Central PMCID: PMCPMC4333334.

148. Li, L., Chen, X., Wang, W. E., \& Zeng, C. (2016b). How to improve the survival of transplanted mesenchymal stem cell in ischemic heart? Stem Cells International, 2016, 9682757. https:// doi.org/10.1155/2016/9682757 Epub 2015/11/22. PubMed PMID: 26681958; PubMed Central PMCID: PMCPMC4670674.

149. Sgroi, A., Gonelle-Gispert, C., Morel, P., Baertschiger, R. M., Niclauss, N., Mentha, G., et al. (2011). Interleukin-1 receptor antagonist modulates the early phase of liver regeneration after partial hepatectomy in mice. PLoS One, 6(9), e25442. https://doi.org/ 10.1371/journal.pone.0025442 Epub 2011/09/27. PubMed PMID: 21980458; PubMed Central PMCID: PMCPMC3181321.
150. Yumoto, E., Higashi, T., Nouso, K., Nakatsukasa, H., Fujiwara, K., Hanafusa, T., et al. (2002). Serum gamma-interferon-inducing factor (IL-18) and IL-10 levels in patients with acute hepatitis and fulminant hepatic failure. Journal of Gastroenterology and Hepatology, 17(3), 285-294.

151. Leifeld, L., Dumoulin, F. L., Purr, I., Janberg, K., Trautwein, C., Wolff, M., Manns, M. P., Sauerbruch, T., \& Spengler, U. (2003). Early up-regulation of chemokine expression in fulminant hepatic failure. The Journal of Pathology, 199(3), 335-344. https://doi. org/10.1002/path.1298.

152. Dinarello, C. A. (2000). The role of the interleukin-1-receptor antagonist in blocking inflammation mediated by interleukin-1. The New England Journal of Medicine, 343(10), 732-734. https://doi.org/10.1056/NEJM200009073431011.

153. Zheng, Y. B., Zhang, X. H., Huang, Z. L., Lin, C. S., Lai, J., Gu, Y. R., et al. (2012). Amniotic-fluid-derived mesenchymal stem cells overexpressing interleukin-1 receptor antagonist improve fulminant hepatic failure. PLoS One, 7(7), e41392. https://doi.org/10. 1371/journal.pone.0041392 Epub 2012/07/23. PubMed PMID: 22844472; PubMed Central PMCID: PMCPMC3402415.

Publisher's Note Springer Nature remains neutral with regard to jurisdictional claims in published maps and institutional affiliations. 